\title{
China's Political Reform as the Key to US-China Relations
}

\author{
SHAOMIN LI \\ College of Business and Public Administration, \\ Old Dominion University
}

\begin{abstract}
Many people believe that economic development will naturally lead to democratization in China. History, however, shows otherwise. Rising economic powers of Japan and Germany in the 1930 s led them to fascism and war. The current U.S.-China-Taiwan relations resemble the U.S.-Japan-China relations before World War II in the sense that the current Chinese regine eagerly wants be a full-fledged member of the international community and to busild a closer relationship with the U.S. while threatening to overtake Taiwan by force. The U.S. should uphold its nonnegotiable principles and make it clear to the Chinese leaders that without initiating democratization, any cordial relationship is impossible. The real progress in China is not the change of leaderships in the communist party; it is the much-needed constitutional reform.
\end{abstract}

Keyuords: U.S.-China relations, China's democratization, China's constitutional reform, China's economic reform

This article is developed from a testimony given at the hearing of the U.S.-China Security Review Commission, U.S. Congress, September 23, 2002, Washington, D.C. I benefited from the discussions wish Xiaokai Yang on this topic. The editorial help by Sonja Sray is gratefuly acknowledged. I would like to thank the members of the U.S.-China Security Review Comnission for their comments on my testimony on this issue. I would also like to thank the two anonymous reviewers of the International Studies Review for their valuable comments, which have helped me to further improve che article. The errors of this article remain solely mine.

Direct all correspondence to Shaomin Li, Associate Professor of College of Business and Public Administration, Old Ibminion University, Norfulk, VA 23529, USA; Tel: 1-757-683-4883; Fax: 1-757-683-5639; E-mail: sli(a) odu.edu 


\section{CHINA'S POLITICAL REFORM AS THE KEY TO US-CHINA RELA'TIONS}

F rom late 2002 to early 2003 , a long-awaited change of leadership was taking P place in the Chinese Communist Party. Before this period, a very small group of people' behind closed doors had secretly determined the fate of 1.28 billion people and their new rulers. With the closing of the party congress and the mecting of National Penple's Congress where the new leaders were chosen, the power succession game is over. Hu Jintao and Wen Jiabao emerged as the new party chief and state premier, respectively. What is the significance of such a power change? How should the U.S. deal with China's new leaders?

The result of the succession game and the ideological leanings of the new rulers in Bcijing may not be as important as many China observers had hoped. I will subsequently discuss reasons for this. What is important for the Lnited States is that the U.S. should use this opportunity to review U.S. policy on China in order to develop a U.S.-China telationship that is not only closely aligned with America's national interest, but also conducive to China's institutional development toward pluralism and the rule of law.

The study of China is heavily skewed toward analyzing the personalities of the parry officials and predicting what they will do based on scant information and unverifiable rumors. Such efforts have failed to produce any theoretical or practical knowledge. The fruitlessness of the effort is reflected by a circulating humor among China observers: the study of $\mathrm{Hu}$ and Wen has become the guess of "who" and "when." In this article, I would like to take a macto-historical approach to offer an alternative perspective on understanding China's political and economic development and its implications for U.S.C.hina relations.

\section{ECONOMIC DEVELOPMENT DOES NO'T AUTOMATICALLY LEAD TO DEMOCRACY}

China's economy has been growing rapidly, and its market has expanded with equal fervor. The prevalent view holds that this economic development will be spontaneously followed by political change in the form of democratization. The international business community, especially executives of multinational corporations doing business in China, clings to this view (Hill 2003, 62). Whilc economic liberalization is a necessary precursor for political liberalization, it does not guarantee the latter

\footnotetext{
We do not know exactly who are in this smail group. The members of the group vary from time to rime, ant there are no explicit reles about who forms it. 'The cormunon betief is chat it is a subset of the seven members of the Standing Commitce of the Polithuro of the $15^{\text {th }}$ Central Commictee of the Chinese Communise Party, three recired nombers of the standing commitec of the politburo, and cwo "party elders" (See Wh
} 
in a definite timeframe. Dictatorship can survive and even be reinforced by economic development for a long period of time. History provides copious examples of economic development that did not lead to democracy.

Before World War II, both Germany and Japan initiated economic revitalization measures and achieved faster economic growth than most other Western countries. For instance, during 1930 and 1935, Japan's industrial output grew 50\%, while that of Germany grew 9\%. In contrast, the industrial output of both France and the United States contracted during the same period. Economic development did not lead to democracy for Japan and Germany; the increased economic power combined with rising nationalism accelerated their march toward war (McClain 2001, 443; Childis 1991, 67-68; Hane 2001, 289).

In today's China, after 25 years of economic reform, the Chinese economy is about 30 times as large as it was a quarter century ago (National Bureau of Statistics 1999, 55). This expanded economy, however, is still ruled by a dictatorial party in a non-democratic society. Recent events indicate that the party has been tightering up its political control while concurrently evidencing no systematic improvement to its violations of human rights. For example, in August 2002, the Chinese government decained Dr. Wan Yanhai, an ALDS activist in Beijing, for leaking "state secrets." The detainment provoked a strong international outcry. Even the United Nations, which has been historically very restrained in criticizing the Chinese government, issued a statement conderning such an action (United Nations 2002).

In September 2002, it was discovered that Chinese Internet users are now blocked from accessing some popular search engines such as Google and Altavista (BBC 2002; Internetnews.com 2002). In fear of being blocked, Yahoo! signed a pledge not to distribute any materials the Chinese government deemed "harmful," per government's request (The Wekly Standard 2002). According to a Harvard University study, the Chinese government blocks over 18,000 worldwide Internet websites (Zittrain and Edelman 2003).

In November 2002, a mysterious, and deadly respiratory disease, later known as SARS (severe acute respiratory syndrome), broke out in Guangdong, China. The nature of China's political sysrem - a nontransparent dictatorship - prompted the Chinese guvernment to conceal information concerning the outbreak. As a result of such a concealment, the outside world did not have any information about the disease until March 2003. Unfortunately by then, the disease had spread all over the world. The outbreak of SARS showed that such a secretive government without checks and balances could produce a governance crises of global magnitude in which not only China, but also the whole world can be adversely affected (Wall Street Journal 2003).

These events demonstrate the futility of hoping that economic development will automacically beget democracy. Ironically, however, China's increased market size and the state's monopoly of business opportunities have enriched the government's power. Control of the entrance gate to the Chinese market allows the government to easily press its advantage with the many foreign companies waiting to enter. By 
clearly dictating the do's and don'ts of foreign companies that want to enter China, such as Yahoo!, the message is clear: If you don't play by the Chinese government's rules, someone else will. This power to hold the entire country hostage gives the Chincse government confidence to violate human rights as it secs fit, for it seems that the multinational companies and even many foreign governments cannot afford to criticize China too much, or they might lose market entry there.

Two examples may illustrate this point. Stephen Roach, chief economist at Morgan Stanley, after spending " 90 minutes in a private meeting with Chinese President Jiang Zemin," concluded, "I must confess the meeting blew me away. It spoke of a Chinese leadership that was thinking well beyond its current ambitious agenda of reforms. Mr. Jiang came across as a risk-taker who was truly committed to the ultimate transformation of the Chinesc economy." Another example was actions by Rupert Murdoch, the owner of News Corp. In order to please the Chinese authoritics, he dropped the BBC from his Star TV network because of the BBC's critical coverage of China, sponsored a trip to the United States for Deng Xiaoping's daughter, and had his publishing firm HarperCollins abandon publication of a book by former Hong Kong governor Chris Patten, whom the Chinese government did nor like (Ching Economic Quarterly 2003).

I use a game in my strategy class (introduced by Adam Brandenburger and Barry Nalebuff 1996) to demonstrate this unequal bargaining relationship. I hold 26 black cards and hand out the 26 red cards to 26 students. A pair of black and red cards will bring $\$ 100$, and an unmatched card will bring nothing. Thereforc, cach student negotiates with me on how we split the $\$ 100$. Since an unmatched card is worthless for the student as well as for me, the students have the same bargaining power as I do. It would be logical to assume that the students and I would split the $\$ 100$ equally. However, I then publicly throw away three cards and begin the negotiation. Realizing that threc of them will have no match, they are desperate to make any deals with me. Sometimes I can get $\$ 99$ for a paired card!

This is what the Chinese Communist Party is doing to the multinational companies and forcign governments. By forcing the forcign companies and governments to follow its rule, the party can play these companies and governments off against cach other.

\section{POLITICAL REFORM AS THE KEY TO U.S.-CHINA RELATIONS}

At the same time, the Chinesc leaders have a compelling desire to become a full-fledged member of the international community and especially to nurture a more cordial relationship with the United States. It is a fair statement to say that they are striving to achieve this. The fact that Chinese President Jiang Zernin paid another visit to the United States in October 2002 and insisted to be invited to President Bush's Texas ranch is an example of this desire.

Certainly, a positive U.S. China relationship is beneficial not only to both countries, 
but also to the world. However, the Chinese leaders seern to have missed the point that without democratization any close relationship with the U.S. is impossible.

The United States upholds a set of core political principles, which are embodied in the Declaration of Independence and the Constitution; among them are liberty, democracy, and the rule of law. In the recently published National Security Strattgy (U.S. Government 2002), the U.S. clearly states:

America must stand firmly for the nonnegoriable demands of human dignity: the rules law; limits on the absolute power of the state, free speech; freedom of wotship; equal justice; respect for women; religious and ethnic tolerance; and respect for private property.

The Chinese leaders are pragmatic, and do not believe in such principles. Principles to them are merely means to rule. They tend to view the U.S. government as fellow pragmatists who will conveniently discard principles as needed. This misperception has led Chinese leaders to believe that China, under the one-party dictatorship, can build a cordial relationship with the U.S. as long as China provides assistance in the war against terrorism. This misperception has served as the compass guiding the Chinese government's policy. The Chinese government's stand on the Taiwan issue provides further evidence.

The Chinese government states that it will use force to overtake Taiwan if the island proclaims its independence. Recently, the people of Taiwan have proposed a national referendum ${ }^{2}$ to decide whether Taiwan should formally declare independence. Such a proposal, which fully reflects the principle of democracy, mects very strong opposition from the Chinese Communist Party (CCP). CCP's stand on Taiwan violates the universally recognized fundamental democratic principle of self-determination (United Nations 1966). To understand this issue, we can take a look at the U.S.-Japan-China relations before World War II.

In the early 1930s, Japan invaded China. This action contradicted the principles of the U.S., and fueled both its strong condemnation of Japan's action and its demand for the Japanese to withdraw. At that time, Japan was heavily relying on the U.S. for trade and desperately wanted to continue its economic ties with the U.S. Conversely, Japan wanred freedom of action in its aggression against China. China remained the thorniest issue berween the U.S. and Japan, an issue that eventually led to the Pearl Harbor attack and the subsequent U.S. declaration of war against Japan (Hane 2001, 315-21).

Today's U.S.-China-Taiwan relations resemble U.S.-Japan-China relations of the World War II era. The current regime in China wants to develop a closer relationship with the U.S. while at the same time advocating the overtaking of Taiwan by any

\footnotetext{
Athough it is called referendum (approving a legislature) in the press, it is actually a plebiscite (initiating a legislatare).
} 
means. The U.S. government should clearly enunciate that as long as China has the intention to use force against Taiwan, a close L.S.-China relationship is not possible. This is simply a restatement of the U.S. government's position on Japan's aggression in China during the 1930 s.

The power succession in Beijing offers a timely opportunity for the new leadership to realize that democratization is the key to the future U.S.-China relations. The U.S. should use this opportunity to clearly convey to the new Chinese leadership that without genuine political reform, the U.S.-China relations cannor be improved.

\section{TAIWAN'S EXAMPLE}

Taiwan's democratization experience provides at least one case study on political reform for the Chinese leadership. Before the late 1980s, Taiwan achieved rapid economic growth without democracy. The Kuomintang's rule was authoritarian and often brought harsh criticisms from the international community, especially from the U.S. Since the early 1980s, the U.S. Congress has been making a series of resolutions urging the authoritarian Kuomintang government in Taiwan to take steps to implement democracy (Sec http://thomas.loc.gov for these bills). For cxample, in 1982 and 1983 the L.S. Congress passed resolutions expressing their concern about martial liaw in Taiwan. In 1984 and 1985, Congress passed resolutions concerning the need to achieve full democracy in Taiwan (U.S. Congress 1982-1987).

The Kuomintang, under Chiang Ching-kuo's leadership, was resiscant to these calls for democracy. This resistance culminated in Henry liu's assassination. In 1984, the Taiwanese government had sent agents to the U.S. to assassinate Henry Liu, who wrote a biography of Chiang Ching-kuo that Chiang did not like (Butterfield 1984). the assassination provoked an international outcry. The U.S. Congress passed resolutions that strongly condemned the killing and demanded that the Taiwanese officials responsible be brought to trial. In 1987, Congress passed resolutions concerning representative government, political partics, and frecdom of expression on Taiwan (sec http://thomas.loc.gov for these bills). The message from the U.S. was very clear: democratize or lose U.S. support. These pressures from the L.S., along with Taiwan's internal forces for change, eventually led to the birth of opposition parties and free press in Taiwan in the late 1980s, which paved the way for 'Taiwan's democratization.

The histories of 'Taiwan's democratization and the U.S.-Japan relations before and after World War II clearly show that democracy is the key for long-term positive and stable relations between any country and the U.S. (I.ynn-Jones 1998).

\section{THE UNPREDICTABLE NATURE OF LEADERSHIP CHANGE}

The long-awaited CCP's $16^{\text {th }}$ Congress in November 2002, and the secretive succession 
game, left China observers to busily guess and decipher what is going on behind the closed doors in Beijing. Academic studies, reports, and analyses abound. However, several factors made such efforts generally unproductive. First, withuut clear rules, the succession game is highly uncertain and chaotic, thus rendering all systemic studies impossible. Second, in contrast to the democratic political process, in the Chinese political selection process one must conceal one's true identity in order to be selected. All these factors make studying the personalities of potential leaders and predicting the succession of the CCP almost useless. Most importantly, the personnel selection process of the CCP makes all survivors opportunists. Grouping them by their political principles or beliefs is futile. For example, someone argued that since Hu Jingtao had spent some time in the western regions, his policy must be in favor of the western regions. Such an "analysis" is no better than to reason that Hu favors raising more pigs if he likes pork. Take the case of Deng Liqun, the leader of the conservative camp. Paradoxically, Deng Liqun was one of the most open-minded reformists in the late 1970s. After he visited the L.S. and Japan during that time, he acknowledged that socialism had lost to capitalism and advocated the abandonment of socialism in China. His open-minded views and reform efforts won him high positions in the party. However, after losing his bid to be the leader of the reform camp, he became a poster child for political opportunism by making a 180 -degtec turn to become the leader of the conservative camp.

\section{CHINA'S MUCH NEEDED CONSTITUTIONAL REFORM}

Thus, 1 tend to pay more attention to the institutional changes that are ongoing in China's political and economic systems. These changes have patterns and are more fundamental. One of the most important institutional changes yet to take place is the reform of China's constitution.

In China, whore the constitution is not taken seriously, four constitutions were produced in a short span of 28 years. The first one, written in 1954, paved the way for abolishing private propetty rights and the dictaturship of the CCP after it seized power in 1949. In 1975, the second constitution was written, reflecting the extreme radical ideology of the Cultural Revolution. In 1976, Mao Zedong died, and the third constitution was written two years later. In 1982, the fourth constitution was written (Cbina Daily 1999). Frequent rewriting of the constitution, as one might imagine, does not cultivate the people's respect for it.

China's current constitution has the following characteristics. It was made without any opposing views, and it provides for no checks and balances of power. It is more like a set of by-laws of "Chinese Socialism, Inc." There is no formal ratification process for the constitution. Instead, the power of the state comes from the communist ideology. It proclaims thac China must follow the "four cardinal principles" - Marxist ideology, CCP rule, people's dictatorship, and socialist road. In sum, the constitution 
gives the CCP unlimited power to pursue its goal to build a socialist state.

Under such a constitution, the CCP pursues its own agenda in the name of public interests. In the conomic domain, the party has been stcadfastly exploiting private businesses and property. From the 1950 s to the $1970 \mathrm{~s}$, the method was outright confiscation. The current constitution states that "socialist public property is inviolable," without conferring the same status to private propertics. Private busincsses are banned from many key industries such as telecom, aviation, post, and international trade, and are restricted from many other industries. Governmental fees imposed on private businesses are so high that the latter must either evade the fees by bribery or go bankrupt. Corruption is the incentive for party officials to carry out dual-tracked economic reform, in which market forces are introduced and party privileges are maintained. The $\mathrm{CCP}$ is the rule-maker, the judge, as well as the biggest player in the economy (Sachs, Woo, and Yang 2000).

In the political domain, persecution of dissidents, suppression of media freedoms, and other violations of basic human rights are done in the name of state security, which is ultimately sanctioned by the "four cardinal principles" in the constitution. These "four cardinal principles" directly contradict many of the citizen rights given in the constitution. When they are in conflict, the cardinal principles override, and the citizen rights are easily swept away. Examples of such conflicts and violations abound. For example, in 2001, the CCP banned people from using sacellite dishes to watch forcign TV programs (Bis News 2002). The ban is in direct violation of each citizen's right to free and private communication, which is mentioned in the constitution. The C.CP routinely violates each citizen's right to organize by arresting and severely punishing people who try to form any political groups. In 2001 , when I went to China to give an invited lecture, I was illegally detained for five months by the Chinese secret police, who charged me with "endangeting state security." All this is done under the "four cardinal principles." "Rule of law" under the state opportunism of the CCP has become "rule by law." Laws exist merely to aid the party in protecting its monopoly.

With economic development and the emerging notion of citizenship, the Chinese people will realize the unconstitutional nature of the constitution and demand constitutional reform. Thus economic reform should be viewed as merely a part of the constitutional transition. The delay of such a transition has enabled the C.CP to maintain a temporary stability, at the cost of institutionalizing corruption and suppression of human rights. The long-term costs resulting from the lack of constitutional reform may outweigh the short-term gains in economic performance.

One of the most important steps in reforming the constitution is to repudiate the "four cardinal principles." When Deng Xiaoping instituted the "four principles," all four were impurtant to him and to his generation. To Jiang Zemin, the most crucial "cardinal principle" is the one-party rule, followed in importance by the people's dictatorship, which is synonymous with party rule. The remaining two, namely Marxist ideology and the socialist road, are increasingly less important to his generation. 
This can be seen from his coining the phrase of "three representatives" (the CCP presents (a) the most advanced productivity force, (b) most advanced culture, and (c) the interests of the largest majority) as the party's new slogan. The central goal of promoting this slogan is to strengthen, not to weaken, the party's absolute rule.

Some China observers argue that the new generation of leaders are better educated, younger (not much though), more technoctatic and pragmatic, and have a broader, worldly view. Thus these observers put a great significance to the leadership change. However, I think the key question remains unchanged. That is, will they give up the one-party rule? No dictatorial party will relinquish its rule unless it faces a strong force of change that cannot be suppressed.

When the pressure for constitutional change is too strong to be suppressed, the change may not be very peaceful. This scenario is not an exaggeration given the fact that the Chinese society does not have a long and deep constitutional tradition or a culture that respects law and order. Therefore, in addition to focusing on leadership successions and some concrete issues, such as trade and human rights, we should pay more attention to the constirutional transition in China.

\section{CHINA'S DEMOCRATIZATION: 'TAIWAN'S BEST DEFENSE}

If China becomes a democracy, will it still use force to overtake Taiwan, in the case that the latter formally claims independence? In answering this hypothetical question, let me quote a key paragraph from a comprehensive review on the relationship between democracy and military aggression by Lynn-Jones $(1998,8)$ :

In addition to improving the lives of individual citizens in new demoxracies, the spread of democracy will benefit the international system by reducing the likelihood of war. Democracies do not wage war on other democracies. This absence ... has been called 'one of the strongest nontrivial and non-tautological generalizations that can be made about internacional relations' (Russett 1990,123 ). One scholar argues that 'the absence of war between democracies comes as close as anything we have to an empirical law in international relations' (Levy 1989, 88). If the number of democracies in the international system continues to grow, the number of porential conflicts that might escalate to war will diminish. Although wars between democracies and nondemocracies would persist in the short run, in the long run an international system composed of democracies would be a peaceful world. At the very lcast, adding to the number of democracies would gradually enlarge the democratic 'zone of peace.'

Both theories and empirical evidence overwhelningly suggest that liberal democracies 
do not go to war with one another. For example, a study by Doyle (1983) finds that there are no cases where democracies go to war against each other. He concludes that "constitutionally secure liberal states bave yet to engage in war with one another" (Doylc 1983,10 , cmphasis in original). The theoretical arguments come from two streams of causal logic. The first stream uses normative explanations; it argues that the shared liberal democratic principles preclude democracies go to war with each other (Doyle 1983). One of the major liberal democratic principles is self-determination. Another principle of liberal democracy is that a democracy should only go to war with a non-democracic regime to liberalize that nation from dictatorship. A second stream of logic argues from an institutionalistructural perspective. They argue that the checks and balances between the three branches of government make waging war difficult, especially unjustified wars that conflict with democratic principles (De Mesquita and Laiman 1992). Therefore, if China becomes a liberal democracy, the libcral democratic principles shared by both China and Taiwan and the checks and balances in the Chinese system would make it extremely unikely for China to wage war on Taiwan simply because the Taiwanese people would vote for independence.

\section{POLICY CONSIDERATIONS FOR THE U.S.}

First, as long as China remains open and wants to be a member of the international community, the Chinese Communist Party must listen to the Linited States; in this sense, the U.S. is perhaps the most credible "opposition party" to the unchecked dictatorship of the CCP in China, a rule that does not only matter internally but causes serious consequences globally and specially to the U.S. Thus, the United States can and should act as a strong "opposition party" that upholds and clearly communicates its principles to the Chinese regime, as stated in the U.S. National Security Strategy (U.S. Government 2002):

We will speak out honestly about violations of the nonnegotiable demands of human dignity using our voice and vote in international institutions to advance freedom.

When forming its China policy, the United Stares should adopt a firm stand regarding these issues. The release of many political prisoners in China, including myself, has shown how that pressure works. The U.S. should make it very clear that without political reforn in China, a close relationship or an alliance with China is impossible. As the National Security Strategy outlined, the U.S. must organize "coalitions - as broad as pussible - of state able and willing to promote a balance of power that favors frecdom." As illustrated in my card game, cach multinational company or country acting alone cannot effectively deal with a regime that wes the whole country as a hostage. In my card grame, the students developed two strategies: collective bargaining and sharing the rotal gains. 
Second, the United States and other democratic nations should take a consistent and collective approach in dealing with the Chinese Communist Party. This approach should be based on a set of universally recognized principles such as the International Covenant of Civil and political Rights. This will make all the democratic nations better off in the long run. From the game-theoretical perspective, when the CCP takes the whole China as hostage to play the democratic countries (or multinational firms) off against each orher, a democratic country (or a firm) would be disadvantaged if it criticizes China's dictatorship, while other countries (or rival firms) are acquiescent. Conversely, if most democratic nations (or multinational firms) cooperate and agree to pressure China to change, the country (or firm) that does not criticize China will get special deals from the CCP. Realizing this outcome, all country (firms) will try not to criticize the CCP. Collcctively, they will lower the international standard for the CCP and reduce the pressure for the C.CP to institute political reforms.

This is what all democratic nations (or multinational firms) must think through. They should realize that their actions, both individually and collectively, will exert a substantial impacr, either positively or negatively, on China's process toward democracy and pluralism.

Third, in addition to focusing on concrete issues such as trade and human rights, the international community, especially the U.S. government, should look at the greater picture of the constitutional transition in China and use economic and political means to help to promote a peaceful transition and to establish constitutional order in China.

One caveat of my analysis is that the international political dynamism by no means follows a pre-determined trajectory. What I outline here is just one of the possible paths that China may take and how some factors may shape the interaction between the U.S. and China. While clearly realizing that there are many unexplained factors that may affect the direction of China's future development, I want to emphasize that such steps as outlined above, namely, a constitutional reform leading to liberal democracy in China, are in the long-term interest not only of China but of the United States and the world.

\section{REFERENCES}

BHC. 2002. China Blocking Google. September 2.

Big News. 2002. Beijing Bans Forrign TV Programs and Satellite Dishes. hetp://www. bignews.org/20020104.sxt.

Boxun (Broad News). 2003. Feidianxing Feiyan (Section on Atypical Pneumonia). http:// www.boxun.com.

Brandenburger, Adan, and Nalebuff, Barry. 1996. Co-opetition. New York: Currency Doubleday.

Butterfield, Fox. 1984. Death of Ctitic of Taiwan Leader Stits Fear anong Chinese in US. New York Times, November 2. 
Childs, David. 1991. Germany in the Twentietb Century. New York: Harper Collins. China Daily. 1999. Backgrounder: Formulation, Revisions of China's Constitution. hetp://www.chinadaily.com.cn/focus/9) npe/r3101.hon.

China Economic Quarterly. 2003. Full on: the 2003 Barton and Rupere Award. Editorial, 2nd Quarter, 30-34.

Dajiyuan (Ep̧xch Times). 2003."Duoming Feiyan Jingbao (Secrion on Warning of the Killing Pneumonia). htcp://www.dajiyuan.com.

De Mesquita, Bruce B, and Lalman, David. 1992. War and Reason: Domestic and Institutional Imperatives. New Haven, CT: Yale University Press.

Doyle, Michacl W. 1983. Kant, Liberal Legacies, and Foreign Affairs. Philosopby and Public Affairs 12, Nos. 3 and 4 (Summer and Fall).

Hanc, Mikiso. 2001. Modem Japan: A Historical Sumey. Boulder, CO: Westuiew.

Hill, Charles. 2003. International Business. 4th ed. Boston: McGraw-Hill.

Internetnews.com. 2002. Altavista Blocked In China. http://internetnews.com (September 10).

Levy, Jack S. 1989. Domcstic Politics and War. In The Origin and Prevention of Major Wars, ed. Robert I. Rotberg and Theodore K. Rabb. Cambridge, LK: Cambridge Lniversity Press.

I.ynn-Jones, Sean, M. 1998. Why the United States Should Spread Democracy. Working paper, Harvard University. htcp://www.ciaonet.org.

McClain, James. 2002. Japan: A Madem History. New York: Norton.

National Burcau of Statistics. 1999. China Statistical Yearbook. Beijing: China Statistical Press.

Russect, Bnace. 1990. Cuntrolling the Suwrd: The Democratic Concmance of National Security. Cambridge, MA.: Harvard University Press.

Sachs, Jeffrey, Woo, Wing T., and Yang, Xiaokai. 2000. Economic Reforms and Constitutional Transition. Working paper, Harvard University.

The Weekly Standard. 2002. China's Dictators Want a Self-censoring Internet: Yahoo! Wants to Help. August 5.

Unitcd Nations. 1966. International Cmenant of Civil and Political Rights. htrp://www. unhchr.ch/html/menu 3ib/a_ccpt.hrm (December 16).

United Nations. 2002. UNAIDS Seeks Information re Missing Chinese AJDS Activist. hctp:/www.un.org/av/radio/news/2002isep/02090600.htm (September 6).

U.S. Congress. 1982-1987. Archives of Legislation Bills by U.S. Congress, http://thomas. loc.gov.

U.S. Government. 2002. National Serurity Strategy. http:/www. whitehouse.gov (September).

Wall Strect Journal. 2003. Quarantine China. March 31.

Wu, Guoguang. 2002. Power Brokering Game. http://www. bignews.org (September 12). Zittrain, Jonathan, and Edelman, Benjamin. 2003. Documentation of Internet Filtering Worldwide. http://cyler.law.harvard.edu/filtering/. 